\title{
Online water quality monitoring: a network to support water management in the Erft river basin
}

\author{
E. Christoffels \\ Erftverband, Bergheim, Germany
}

\begin{abstract}
A clear picture of the dynamic processes of river water quality, in particular for a river such as the Erft with low mean water flow combined with intensive water use, cannot be obtained through simple spot checks. For this reason, twenty-three years ago the Erftverband, a water management association in North RhineWestphalia (Germany), initiated an online monitoring network consisting of six water quality monitoring stations for continuous recording of contents of surface water in the Erft catchment. Measurement data combined with physicochemical and biological data from routine spot checks is processed at a central facility to yield information needed to assess and if necessary to improve water quality. Examples of such information are presented. The considerable advantages for river basin management planning are disclosed.

Keywords: water quality, online monitoring, in-situ station, on-site station, water temperature, oxygen, nutrients, nitrate, phosphorus.
\end{abstract}

\section{Introduction}

Water quality in the Erft and its tributaries requires considerable attention because usage demands are high relative to the modest size of these watercourses. Some background on the river and its uses will help explain why the Erftverband established online monitoring.

The source of the Erft is situated 45 kilometers southwest of the former German capital, Bonn, in the federal state of North Rhine-Westphalia. Near the city of Euskirchen the river, with an average 1\% slope of decline, leaves the hilly region called the Eifel. In the middle and lower reaches the Erft descends at a 
very gradual slope of $0.1 \%$ until the end of its $110 \mathrm{~km}$ course, where it joins the Rhine river near the city of Düsseldorf.

Wide areas of the river basin are dominated by cultivation of field crops including wheat, rye, barley and sugar beets. In addition, the region is well known for its open pit lignite mines. Large quantities of groundwater must be pumped out to keep these mines dry. About 250 million cubic meters per year of this so-called sump water is discharged in the middle reach of the Erft [1] and thus determines the level of flow in the middle and lower portions of the river. The mean runoff at the mouth is around twelve cubic meters per second, of which the natural runoff amounts to only about 3 cubic meters per second.

Besides extensive cultivation of field crops and brown coal extraction, some other significant factors impact the Erft river:

- Discharge from wastewater treatment plants, combined sewer overflows and separate sewer outlets

- Discharge from flow components of the landscape (surface and subsurface flow)

- Gathering of water for heat exchange at (coal burning) power plants

- Abstraction of water to preserve aquatic biotopes and for intensive fruit and vegetable production, and

- Recreation (e.g. sportfishing, boating).

This wide variety of claims on the river is best satisfied if the water is of good quality. Collecting data on the contents of the water is an important first step in planning a course of action to assure the desired water quality in accordance with the European Water Framework Directive [2].

\section{Characterisation of online monitoring}

An online monitoring system to assess water quality in rivers is a technical facility (water quality station) with which key water-related parameters are automatically and continuously measured. The measuring point can be in the water body or in a bypass system. Measurement data recorded on a computer are transmitted automatically or on request to a central facility. In the central facility, the data are processed to yield useful information for ascertaining the status of the watercourse and for planning appropriate measures to improve water quality.

Within a comprehensive monitoring strategy, an online monitoring network for continuous measurement of significant water contents at selected sampling points diminishes the dilemma of time-related gaps which is inherent in grab sampling. Continuously collected concentration data together with continuously recorded flow data provided by water runoff gauges enables calculation of load for water-soluble substances in the river.

In a small to medium-sized river with low flow volume and high water demand for diverse uses, the ability to track dynamic substance fluctuations in 
defined river sections is particularly important. By dynamic substance fluctuations are meant changes related to

- diurnal cycle

- precipitation events

- seasonal effects

- operational problems at technical plants (industry, sewage treatment)

- medium- and long-term trends of water quality.

Two methods of online monitoring can be distinguished, depending on where the measurement system is located. If the monitoring point and the measurement point are the same, it is called the in-situ method (figure 1, left). This means that the measuring instruments are placed directly in the water body. As the measuring instruments must be operated without reagents, the number of parameters is limited. In addition, various complications may arise:

- Disruptions through watercourse maintenance measures

- Damage or loss caused by vandalism.

In-situ measuring stations are difficult to protect from external interference. For this reason, they are often placed in areas that are not accessible to the public, such as industrial sites or private grounds.
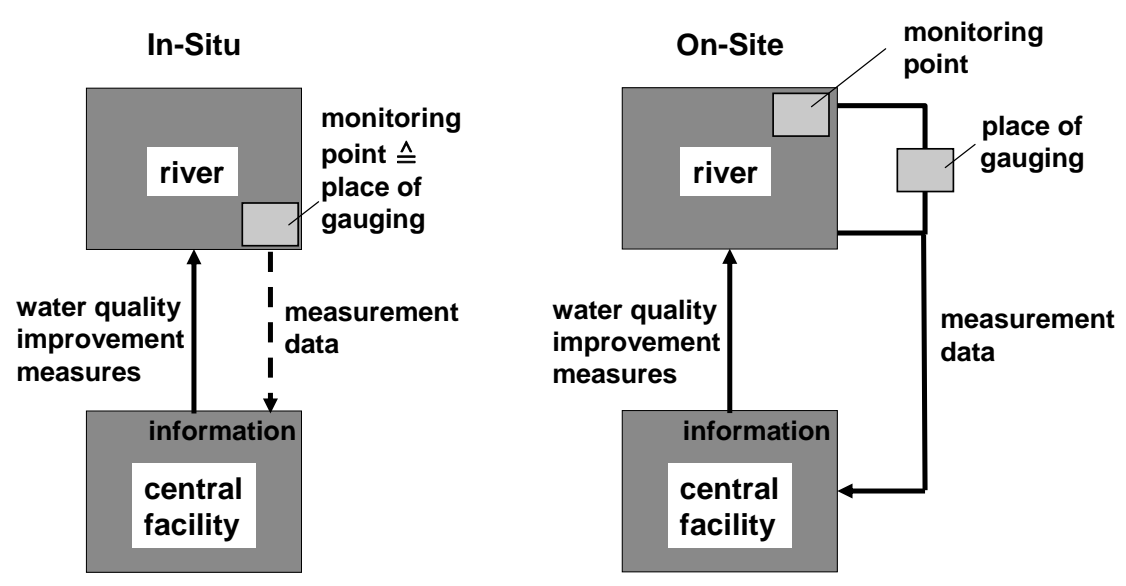

Figure 1: $\quad$ In-situ (left) and on-site monitoring (right).

The other system of online monitoring is the on-site method (figure 1, right). The monitoring point and the location of measurement are different, in contrast to the in-situ method. Samples are gathered from the water column and 
transported via a bypass system to a water quality station, where measurement takes place.

Advantages of on-site method:

- Greater protection of equipment against possible external influences

- Equipment protected from extreme weather conditions

- Optimal conditions for maintenance and repair

- Large number of parameters because of ability to employ reagents.

Disadvantages of on-site method:

- Large number of system components

- High operating cost

- No mobility

- Risk of transformation of physicochemical properties of samples during transport in bypass system.

\section{Online monitoring in the Erft catchment}

Over the last twenty-three years the Erftverband, in addition to conducting monitoring campaigns by means of grab sampling in a fixed temporal frequency, has operated an online monitoring network for continuous measurement of significant water contents at selected sampling points. Figure 2 shows the flow

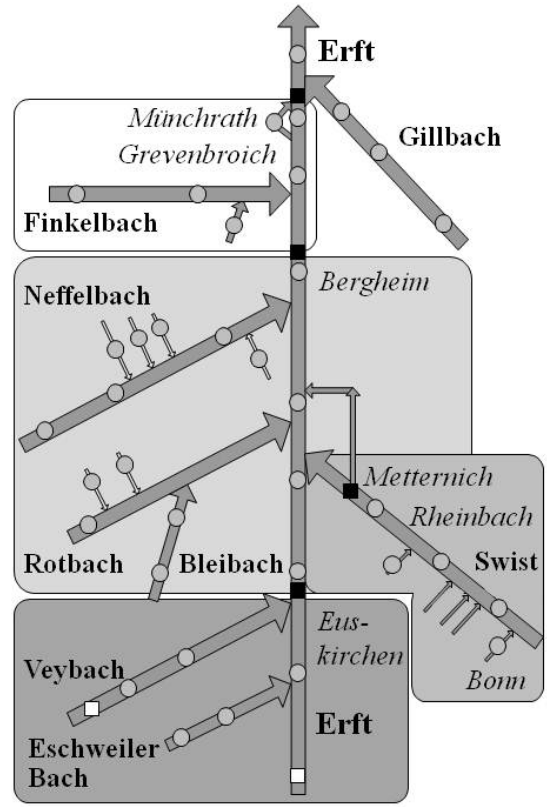

Monitoring zones

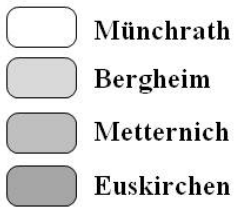

$\square$ In-situ monitoring

On-site monitoring

Wastewater treatment plants

Figure 2: $\quad$ Flow diagram of the Erft with online monitoring and municipal wastewater treatment plants, status: 2011. 
diagram of the Erft and its main tributaries, water quality monitoring stations and locations of municipal wastewater treatment plants.

Two in-situ water quality monitoring stations are established in the Erft river basin. One is located downstream from a flood retention reservoir in the upper reaches of the Erft river. This reservoir is situated directly in the course of the river and is always filled with Erft water. Particularly during the growing season the dissolved oxygen concentration in the Erft downstream of the flood storage basin can be critical, daytimes too high and nighttimes too low, due to the activity of algae.

The other in-situ station is located at the drainage outlet of a disused ore mine, along a creek called the Veybach, in the upper part of the Erft catchment. The mine shaft employed for drainage is subject to cave-in. Blockage by fallen debris would cause water level in the shaft and mine gallery to rise and reach weatherbeaten, heavy-metal-laden minerals in the rock walls. Nickel, zinc, cadmium and cobalt would be eluated in extraordinarily high concentrations. The monitoring station is vital for early detection of increased turbidity or reduced flow, signs of disturbance inside the mine.

The first of four on-site water quality monitoring stations is situated at the Euskirchen wastewater treatment plant downstream of the town. This station provides data on the upper reach of the Erft, where the water quality is influenced by tributaries originating in the Eifel hills. Water quality is also affected by discharge from municipal wastewater treatment plants and in case of heavy rainfall by discharge from combined sewer systems which receives only primary (mechanical) treatment. This upper stretch of the Erft is also directly affected by the aforementioned discharge stemming from the disused former ore mine.

Further downstream, a significant tributary affecting Erft water quality is the Swist river. For this reason, at the mouth of the Swist, near the village of Metternich, a water quality monitoring station has been installed (on the site of a former sewage treatment plant). Swist water quality is influenced by diffuse discharge from arable land, direct discharge from municipal wastewater treatment plants in the Rheinbach area and, in case of heavy rainfall, by the outflows of large sewerage networks, primarily combined sewer overflows.

The third on-site station is situated downstream from the town of Bergheim. This station provides an overview of the water quality situation in the middle reach of the Erft, which is subject to a variety of significant influences. The large volume of sump water pumped out of the lignite mining area enters the river in this Bergheim monitoring zone. Between the water quality stations of Euskirchen and Bergheim the main tributaries Swist, Rotbach and Neffelbach meet the Erft. Furthermore, the majority of wastewater treatment plants in the Erft basin are located in this monitoring zone.

The last on-site water quality station, at the village of Münchrath, is placed on the site of a river maintenance depot near the mouth of the Rhine, below the city of Grevenbroich. Three of the largest wastewater treatment plants in the catchment are situated in this section. 
All four on-site water quality monitoring stations are almost identical in design and selection of parameters. The following parameters are measured:

- Water and air temperature

- Oxygen concentration

- Conductivity

- $\mathrm{pH}$ value

- Turbidity

- Nitrogen compounds (ammonia, nitrite / nitrate)

- Orthophosphate phosphorus.

Additional measurements are taken depending on local conditions. At the Euskirchen station the water-soluble metal nickel is continuously recorded because of the ongoing risk of metal emissions from the disused ore mine. At the Bergheim station total iron is measured, as the discharged sump water from the lignite mine is loaded with significant amounts of iron. To obtain a view of the influence of solar radiation (e.g. on algae growth), a pyranometer has been installed at the Metternich station. By registering solar radiation meeting the water surface, the device helps to provide a general overview of daily and seasonal distribution of radiation.

Figure 3 shows the interior view of the Münchrath station. Further clarification of technical equipment features at the online water quality monitoring stations is available in another paper [3].

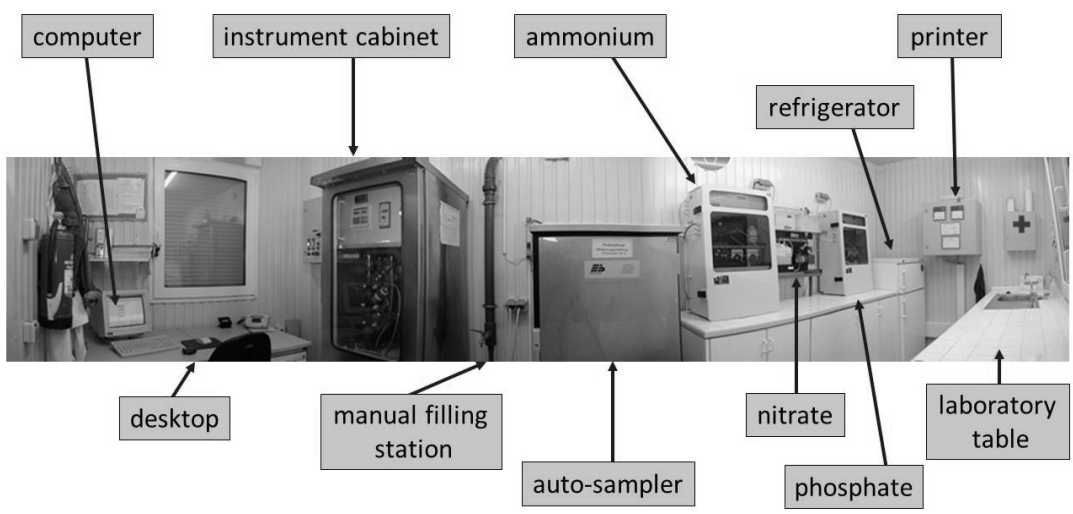

Figure 3: $\quad$ Inside view of Münchrath water quality monitoring station.

\section{Online monitoring results}

Results based on recorded data from the three monitoring stations situated along the main watercourse are presented. Significant findings are briefly explained. 


\subsection{Water temperature}

Figure 4 shows the annual hydrographs of Erft water temperature for the year 2011 as daily averages measured in the Euskirchen, Bergheim and Münchrath stations. In the upper reach (Euskirchen), which provides habitat for salmonids and grayling, water temperature is influenced by cool tributaries descending from the Eifel hills. During summer months, $20^{\circ} \mathrm{C}$ is seldom exceeded. In winter, daily temperature drops significantly below $10^{\circ} \mathrm{C}$ to a minimum of around $3^{\circ} \mathrm{C}$ (grayling spawning temperature $5-7^{\circ} \mathrm{C}[4]$ ).

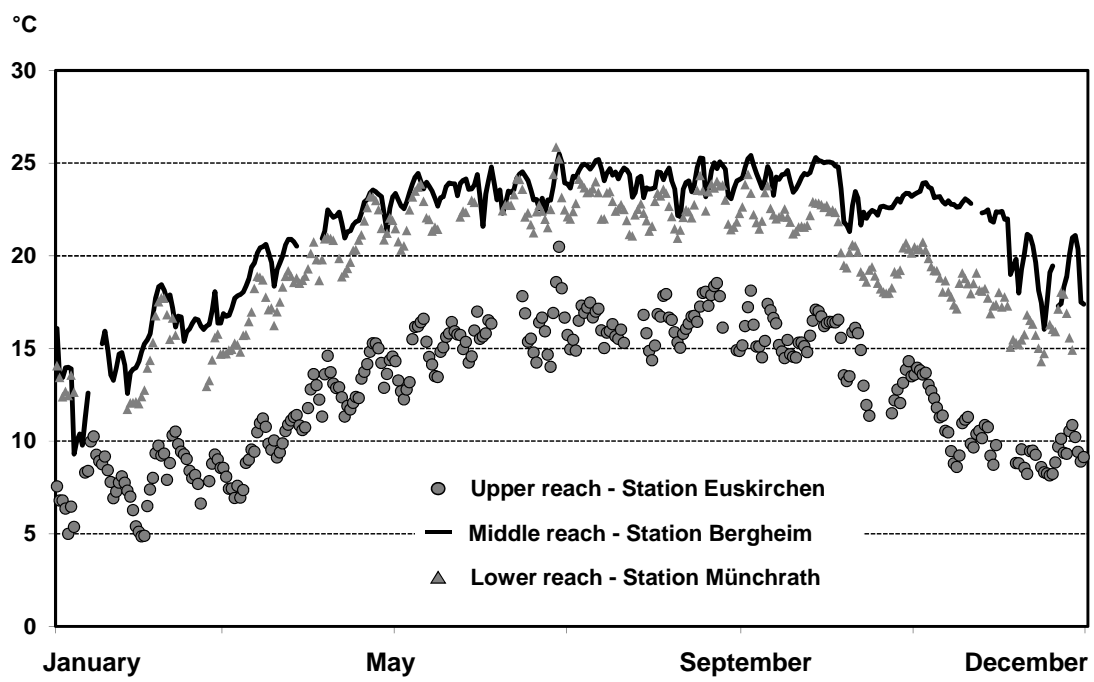

Figure 4: Annual hydrographs of the Erft water temperature (daily average) for the year 2011.

Water temperature in the middle reach (Bergheim) is significantly higher all year round than in the upper reach due to discharge of sump water. Here, water temperature in winter rarely falls below $10^{\circ} \mathrm{C}$. During summer, temperatures of $24^{\circ} \mathrm{C}$ are regularly measured. In summer season the difference in temperature between the middle and upper reaches amounts to around $6^{\circ} \mathrm{C}$; in the winter months a difference of up to $10^{\circ} \mathrm{C}$ has been recorded.

Temperatures measured at Münchrath station near the mouth of the Erft approximately equal those recorded in the middle reach at Bergheim (spatial distance: Münchrath - Bergheim $=27 \mathrm{~km}$ ). Heat loss through exchange via the water surface between Bergheim and Münchrath is low, even in winter months with a high temperature gradient between the warm water body and the surrounding cool air layer. As the cross section profiles in these river segments are strongly channel-like, wetted perimeter and water surface are low in comparison to naturally structured river profiles. Heat flow from the water body to the adjacent soil body and heat loss via the water surface through evaporation and convection are limited. 


\subsection{Oxygen}

The amount of available data generated by the water quality measurement network allows presentation of results as representative frequency distributions (figure 5). The figure shows that oxygen frequency polygons in year 2011 for the upper, middle and lower reaches of the Erft are significantly diverse. In the upper reach oxygen is symmetrically distributed (mean and median $=10.5 \mathrm{mg} / \mathrm{L}$ ) over a range of 5.4 to $15 \mathrm{mg} / \mathrm{L}$. Oxygen concentrations in the lower Erft are distributed within a lower range of 6.5 to $12 \mathrm{mg} / \mathrm{L}$ (mean and median $=7.1$ $\mathrm{mg} / \mathrm{L}$ ). Oxygen content in the middle reach is significantly scattered. Often, oxygen concentrations are low (modal value $=6.5 \mathrm{mg} / \mathrm{L}$ ). The sump water, which enters the river with about $5 \mathrm{mg} / \mathrm{L}$ dissolved oxygen, is the reason for lowering of oxygen concentrations in the middle reach. In contrast, 53\% of observed oxygen concentrations at Bergheim station are above $7 \mathrm{mg} / \mathrm{L}$. These higher oxygen levels are associated with reduced sump water discharge (relative to the maximum sump water discharge of $8.5 \mathrm{~m}^{3} / \mathrm{s}$ ). When sump water discharge is low for operational reasons, higher oxygen content is measured at the Bergheim station.

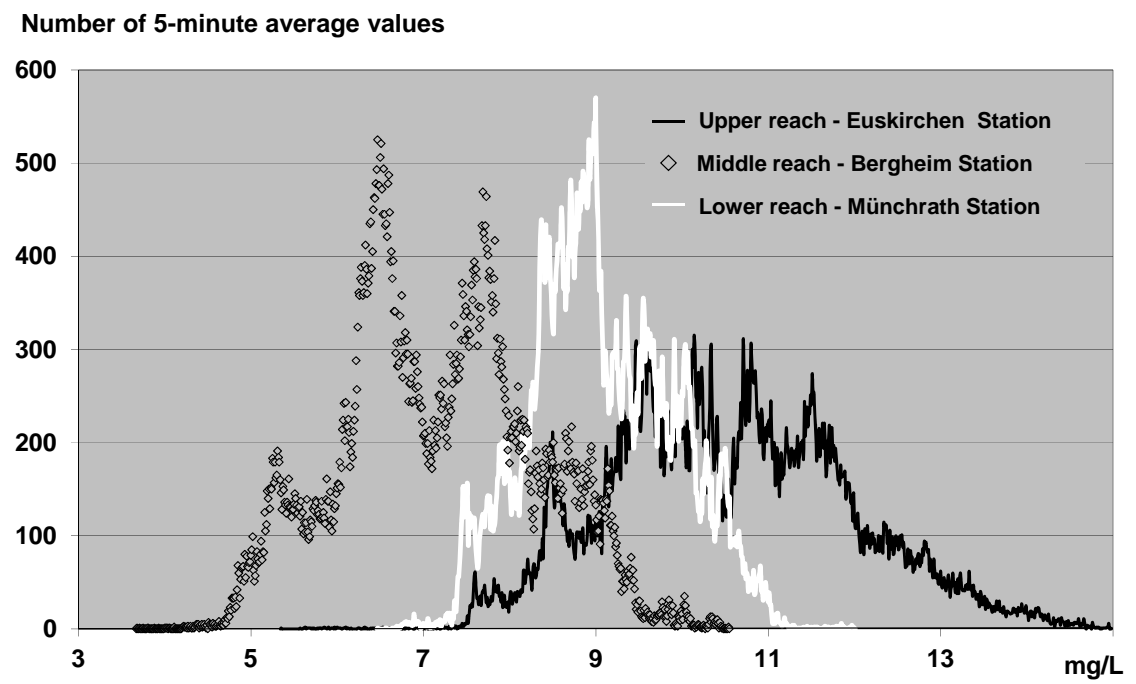

Figure 5: Absolute frequency distributions of the oxygen content of the Erft in year 2011.

Measured oxygen concentrations are depicted as relative frequency distributions in figure 6. Also depicted are 50-percentile values and for the middle reach the guide and imperative thresholds of the Fish Waters Regulation of North Rhine-Westphalia (NRW) [4] (table 1). For the upper reach of the Erft, the relative frequency distribution curve of oxygen content in the year 2011 
shows that the rigorous oxygen criteria for the zone containing salmonids are not violated $(100 \% \geq$ imperative threshold of $6 \mathrm{mg} / \mathrm{L})$.

Table 1: Thresholds for oxygen concentrations [mg/L] according to NRW Fish Waters Regulation [4].

\begin{tabular}{|c|c|c|}
\hline & Guide & Imperative \\
\hline \multirow{2}{*}{ Salmonids } & $50 \% \geq 9$ & $50 \% \geq 9$ \\
& $100 \% \geq 7$ & $100 \% \geq 6$ \\
\hline \multirow{2}{*}{ Cyprinids } & $50 \% \geq 8$ & $50 \% \geq 7$ \\
& $100 \% \geq 5$ & $100 \% \geq 4$ \\
\hline
\end{tabular}

\section{Oxygen mg/L}

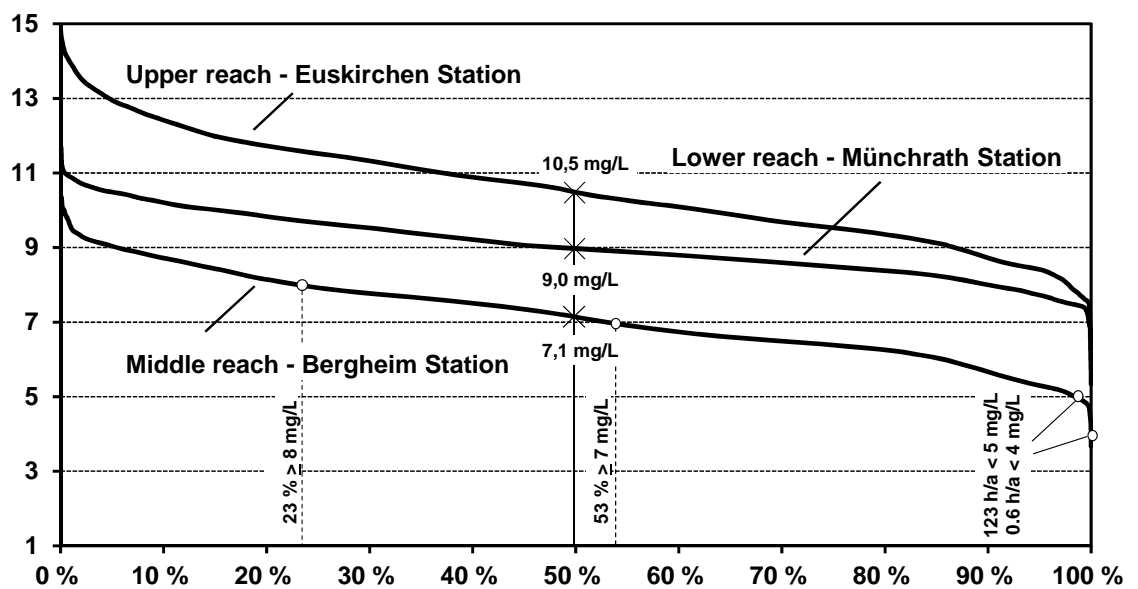

Figure 6: Relative frequency distribution of oxygen, Erft river 2011, plus 50percentile values; middle reach (cyprinids river section): proportions of oxygen concentrations per year in accordance to guide / imperative thresholds referred to Fish Waters Regulation NRW [4]

In the middle reach, the cyprinids river zone, oxygen concentrations are entirely different. Here, the imperative and guide values for cyprinids, $100 \% \geq 4$ $\mathrm{mg} / \mathrm{L}$ and accordingly $\geq 5 \mathrm{mg} / \mathrm{L}$, are not being met consistently. However, the shortfalls of 0.6 hours per year $<4 \mathrm{mg} / \mathrm{L}$ and 123 hours per year $<5 \mathrm{mg} / \mathrm{L}$ are relatively low. Data obtained from Bergheim station indicates that the $50 \%$ imperative value for cyprinids is satisfied by a small margin (53\% vs. 50\% $\geq 7$ $\mathrm{mg} / \mathrm{L}$ ) but the $50 \%$ guide value is quite clearly not met ( $23 \%$ vs. $50 \% \geq 8 \mathrm{mg} / \mathrm{L}$ ). In contrast, the guide value in the lower reach $(50 \% \geq 8 \mathrm{mg} / \mathrm{L})$ for cyprinids is fulfilled, with $94 \%$ above $8 \mathrm{mg} / \mathrm{L}$. 


\subsection{Nutrients}

The continuously operating water quality monitoring stations provide basic information on general levels of nutrient contents and their seasonal distributions. Results with the examples of phosphorus and nitrate nitrogen are presented.

\subsubsection{Phosphorus}

Besides a low continuous input of phosphorus into Erft basin waters from municipal sewage treatment plants, additions via surface runoff from grassland and agricultural land (fertilizer, animal waste, crop residues, soil erosion) during the growing season must be considered. At those times phosphorus is typically released through

- Decomposition of vegetation residue

- Delivery of phosphate, which is stored in biomass, as a consequence of bacterial and algal metabolism or die off

- Phosphate uptake by macrophytes via rhizomes and delivery via sprouts

- Diffusion from aerobic sediments into the water column

- Resuspension of sediment through activity of macrozoobenthon (e.g. chironomids) or riverine channel erosion (phosphate in pore water 10-50 times higher than in the water column [5])

- Bacterial reduction of iron oxides and release of phosphate (e.g. in anaerobic upper layer of river sediment [6]).

Given these factors, it is hardly surprising that measured phosphorus concentrations are significantly higher in spring and summer than in winter months (figure 7). This cannot be explained by seasonally reduced dilution due to low water flow during the growing season $[6,7]$, as runoff measured in the summer months is not significantly lower than that measured in winter.

\subsubsection{Nitrate}

In summer months higher orthophosphate concentrations are measured in the Erft than during winter. For nitrate nitrogen, the situation is reversed (figure 7). In the summer half-year nitrate nitrogen levels in the Erft are low, while nitrogen demand of crops is high. Also, nitrate can be removed by denitrification, because during the summer season water movement in the soil layer is mostly low [8]. In late autumn, nitrate accumulates in the soil, since nitrogen demand is low. In the winter season soil moisture is significantly higher than in summer months. The enriched, highly soluble nitrate is leached from the soil and enters the river via interflow $[6,9]$. The measurement data of the Bergheim station clearly shows the opposite seasonal trends for nitrate and phosphorus. 


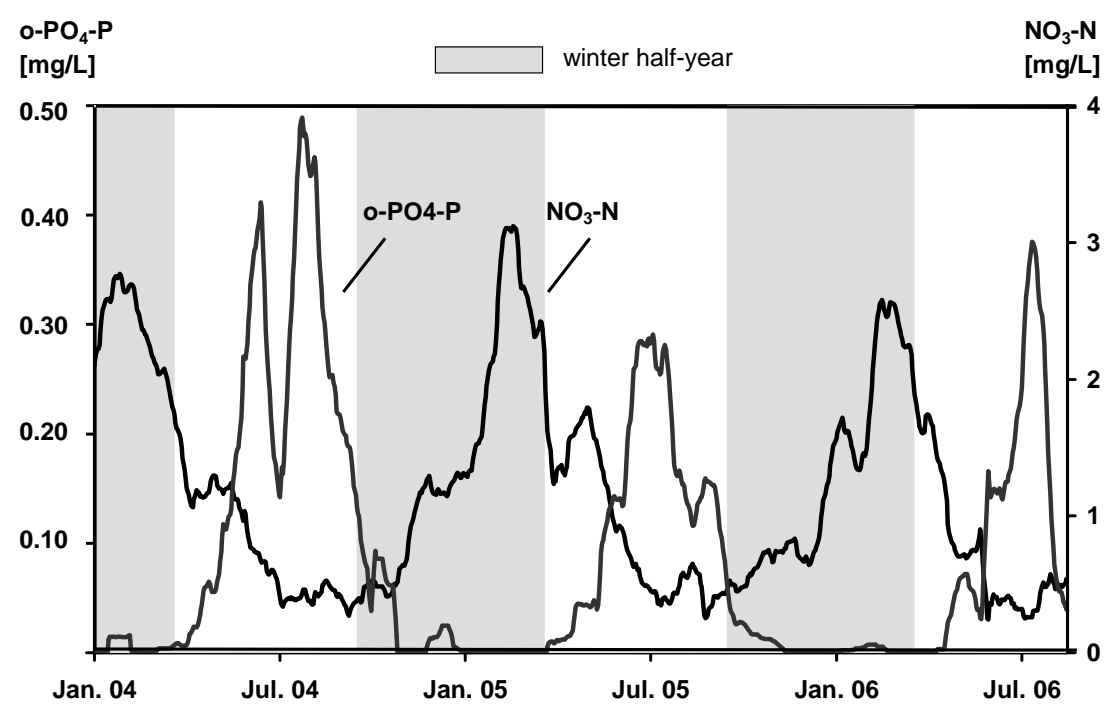

Figure 7: Hydrographs of orthophosphate phosphorus and nitrate nitrogen concentrations for years 2004 to 2006 in the middle reach of the Erft (Bergheim water quality monitoring station, simple moving average of order $n=20$ ).

\section{Discussion and conclusions}

For important water-related parameters, information from the online monitoring system yields hydrographs which display clear patterns. The knowledge gained can help in identifying existing problems, in determining potential solutions or in assessing effectiveness of remedies undertaken.

Regarding water temperature, it is evident that the Erft middle reach is heavily influenced by warm sump water discharges. This creates a substantial gradient with the upper reach. To maintain good ecological status, the German Surface Water Ordinance stipulates an upper limit of 3 Kelvin for differences in water temperature arising from discharges in potamal river sections [10]. This limit is substantially exceeded throughout the year. From the middle reach down, the required cool spawning temperatures for individual fish species are not achieved. As a solution, it is currently being planned to separate particularly warm sump water and to conduct it to the Rhine instead of the Erft.

The deprived oxygen level of the river is also caused by the sump water discharge. A promising new system of oxygen enrichment of the sump water before inflow to the Erft has been put into operation. It is expected that oxygen content in the middle reach will be permanently increased.

The continuous records of the nutrient content of phosphate and nitrate show opposite seasonal concentration gradients. The capabilities of wastewater treatment plants have already been enhanced to permit further removal of nutrients (e.g. average effluent concentration $\mathrm{P}_{\text {total }}=0.4 \mathrm{mg} / \mathrm{L}$ ). In accordance 
with requirements of the German Surface Water Ordinance, additional measures under consideration include reduction of fertilizer amounts and optimised fertilizer application, measures to prevent soil erosion and establishment of riparian zones in agricultural areas.

The preceding examples demonstrate that in such areas as the Erft river basin, with significant external impacts upon the watershed and high pressure from competing water uses, a continuous online water quality monitoring system is a useful tool to deliver information which can be used for river basin management planning.

\section{References}

[1] Erftverband Jahresbericht, Bergheim, 2011.

[2] European Commission. Directive 2000/60/EC of the European Parliament and of the Council of 23 October 2000 Establishing a Framework for Community Action in the Field of Water Policy. Office Journal L 327/1, 2000.

[3] Christoffels, E., Online Monitoring of Water Quality on the River Erft, ISSN 1994-8549, E-WATER EWA, 2008.

[4] Fish Waters Regulation NRW, Verordnung zur Umsetzung der Richtlinie 78/659/EWG des Rates vom 18.Juli 1978, ABl.EG Nr. 377 S. 48, 2006.

[5] Besch et al., Limnologie für die Praxis, Grundlagen des Gewässerschutzes, ecomed Verlag Landsberg, ISBN 3-609-73150-8, 1984.

[6] Hamm, A., Studie über Wirkungen und Qualitätsziele von Nährstoffen in Fließgewässern, Academica Verlag Sankt Augustin, ISBN 3-88345-380-3, 1991.

[7] Koppe, P., Stozek A., Kommunales Abwasser, 4. Auflage, Vulkan Verlag Essen ISBN 3-8027-2833-5, 1999.

[8] Peters, N. E. and Walling, D. E., Sediment and Stream Water Quality in a Changing Environment: Trends and Explanation, IAHS Press, Institute of Hydrology, Wallingford, Oxfordshire, ISBN 0-947571-08-6, 1991.

[9] Brehm, J., Meijering, M., Fließgewässerkunde, Einführung in die Limnologie der Quellen, Bäche und Flüsse, Heidelberg, ISBN 3.49401061-7, 1982.

[10] German Surface Water Ordinance, Bundesrat. Drucksache 153/11 (Beschluss). Verordnung zum Schutz der Oberflächengewässer, Oberflächengewässerverordnung - OgewV, 2011. 